\section{Aquaculture}

Vol. 260, Issues 1-4 , 29 Sept. 2006, Pages 337-345

http://dx.doi.org/10.1016/j.aquaculture.2006.06.005

(C) 2006 Elsevier
Archimer, archive institutionnelle de l'Ifremer http://www.ifremer.fr/docelec/

\title{
Energy balance of Litopenaeus vannamei postlarvae fed on animal or vegetable protein based compounded feeds
}

\author{
Luis Jiménez-Yan ${ }^{\underline{a}}$, Abelardo Brito ${ }^{\underline{b}}$, Gerard Cuzon $\stackrel{c}{ }$, Gabriela Gaxiola $a^{\underline{b}}$, Tomás García ${ }^{\underline{b}}$, Gabriel \\ Taboada ${ }^{\underline{b}}$, Luis A. Soto ${ }^{\underline{d}}$ and Roberto Brito ${ }^{\underline{e}}$
}

\author{
aUniversidad Juárez Autónoma de Tabasco, Extensión Universitaria de los Ríos, Tenosique de Pino Suárez, \\ Tabasco, México \\ bUnidad Multidisciplinaría de Docencia e Investigación, Facultad de Ciencias UNAM, Sisal, Yucatán, México \\ 'IFREMER, COP-Tahiti, France \\ 'Laboratorio de Ecología del Bentos, Instituto de Ciencias del Mar y Limnología, UNAM, México \\ ${ }^{\mathrm{e}}$ Facultad de Ciencias Pesqueras, Universidad Autónoma del Carmen, Calle 56 No. 4, CP 24180, Cd. del \\ Carmen, Campeche, México
}

Corresponding author : rbrito@pampano.unacar.mx

\begin{abstract}
:
L. vannamei postlarvae are normally raised with a protein dense diet (50\% protein) rich in fishmeal. Part of the protein is utilized for energy purpose instead of protein synthesis. Based on a previous energy partitioning study, the effects of two isoenergetic compounded feed treatments - animal protein (AP) and vegetable protein and carbohydrates (VPC) - upon growth efficiency and energy budget of shrimp postlarvae and early juveniles were determined. Recovered energy (RE) or production $(P)$ after 50 days trial was similar ( $2 \mathrm{~J}$ day- 1 ) in both treatments, from PL14 to PL19. However, early juveniles discriminated between animal protein (116 J day -1$)$ and vegetable protein and carbohydrates (88 J day-1). The difference in respiration indicated a higher heat increment with AP compared to VPC. At maintenance level, energy used was lower with AP than VPC treatment. Postlarvae and early juveniles employed protein as a main energy substrate (O:N<20). Differences in the efficiencies observed in the calculated energy budget were attributed to the presence of carbohydrates in diet and not to the protein source. The advantage of incorporating vegetable protein source in the diet of harvesting shrimp may eventually contribute towards a reduction of fishmeal costs and waste products as well as to achieve sustainable shrimp farming
\end{abstract}

Keywords: Postlarvae; Juvenile; Energy; Animal protein; Vegetable protein; Physiology; Shrimp 


\section{Introduction}

Our current knowledge on the nutritional requirements of penaeid shrimp postlarval stages (PL's) is still limited. Few studies have been conducted on vitamins, lipids, proteins, and essential minerals needed for their development (Colvin and Brand, 1977; Rees et al., 1994; Camara et al., 1997; Sheen and Huang, 1998; Velasco et al., 1998; Immanuel et al., 2001). The digestive tract of postlarvae goes through several developmental stages (Lovett and Felder, 1989; Lovett and Felder, 1990a, 1990b, 1990c) before reaching its definitive structure with numerous hepatopancreas diverticula and full physiological functions. At PL stages also the feeding habits change in relation with the shift from planktonic to benthic habitats (Escobar-Briones, 1988; Garcia and Le Reste, 1981), as they immigrate from oceanic waters to the estuarine nursery grounds in coastal waters, particularly into mangrove systems (Dittel et al., 1997). In this environment, postlarvae adopt an opportunistic feeding strategy. However, there has been no strict determination of nutritional requirements in relation to their feeding activity under controlled conditions. Presumably, an opportunistic omnivorous invertebrate is capable of digesting most of the nutrients contained in its food, and shrimp postlarvae are not exception. Then, it would be highly relevant for the energy balance of PL's to establish possible differences in the digestion and absorption of food rich either in animal or plant protein and digestible carbohydrates (cbh).

There used to be a critical phase at $M_{1 I I}-P L_{1}$ with a shift from live food sequence (algae-Artemia) to dry pellet (crumbles) (Aquacop, 1995). Since inert particles replace live food sequence during larval stages, the problem of weaning does not exist anymore. The obtainment of hardy postlarvae depends on feed quality and the feeding schedule applied at larvae stages (Gallardo et al., 2003). Whereas the adaptation to a category of protein sources and to a protein and carbohydrate balance at PL's stages will depend primarily on the composition of microcapsules provided at larvae stages.

Inert particles can replace live food sequence without significant difference in development duration. However, a more critical situation may arise when animal protein is replaced with vegetable protein sources (Argue et al., 2001).

Postlarval stages provide a good material to measure energy budget and to evaluate the respective growth promotion effects of feeds (whether under moist form or extruded with animal and/or vegetable protein sources). Several studies (Lemos and Phan, 2001; Lemos et al., 2001; Brito et al., 2004) provided methodology and results on energy expenditure; energy partitioning at PL's stages when replacing Artemia with inert particles or effect of salinities, proved feasible from a comparative point of view. Consequently, the PL's overall energy budget can be addressed in spite of an existing difficulty to assess feed intake with precision.

This paper addresses the comparative effects on growth efficiency and energy budget of L.vannamei postlarvae and early juveniles -previously weaned on inert particles- while being exposed to two types of diets: one composed of vegetable protein and carbohydrates (soybean soluble protein concentrate, Spirulina powder, wheat gluten, and wheat starch) and another containing animal protein sources (fish, squid, and shrimp meals, and fish soluble protein concentrate). 


\section{Material and Methods}

Experimental shrimp

L. vannamei postlarvae from $8^{\text {th }}$ generation farmed population obtained from a commercial hatchery (Grupo Pecis, Yucatan, Mexico) were transported to the laboratory as postlarvae 14 ( $\mathrm{PL}_{14}$, fourteen days after metamorphosis). Postlarvae (1.08 mg wet weight) were transferred to 25-L plastic tanks, stocked at a density of $30 \mathrm{PL}$ per tank and acclimatized at $28 \pm 0.05^{\circ} \mathrm{C}$ and $32.4 \pm 0.1 \%$ salinity, photoperiod (13-h:11-h, light: dark). Tanks were supplied with constant aeration maintaining oxygen near saturation levels $\left(6.3 \pm 0.04 \mathrm{mg} \mathrm{O}_{2} \mathrm{~L}^{-1}\right)$. Sand filtered seawater was filtered through 5 and $1 \mu \mathrm{m}$ cartridges and UV sterilized before a $50 \%$ daily exchange.

Diet preparation and feeding schedule

Postlarvae were fed two artificial diets. One group was fed an animal protein based diet $(A P)$, and the other was fed a vegetable protein concentrate plus carbohydrate (VPC). Proximate composition of both experimental feeds (Table 1) was similar. The experimental feeds were prepared in the laboratory by thoroughly mixing dry ingredients with oil and then adding water until a firm mass was obtained. The mass was passed through a meat-grinder equipped with a $2 \mathrm{~mm}$ die, and resulting strands were air dried at $60^{\circ} \mathrm{C}$. After drying, pellets were broken, sieved to a convenient size and stored at $-4^{0} \mathrm{C}$ until use. At the beginning of the experiment $250-350 \mu \mathrm{m}$ crumbles were used, increasing its size up to $800-1000 \mu \mathrm{m}$ at the end of the experiment. Animals were fed three times daily (0800, 1400, and 2000), and food ratio adjusted every fortnight as $300 \%$ of the biomass from day 0 to 15 , then $200 \%$ of the biomass from day 15 to 30 , and in final $80 \%$ of the biomass from day 30 to 45.

Energy balance

The amount of energy channeled into growth $(P)$, maintenance $(R)$, excretion $(U)$, and exuviae $\left(E_{v}\right)$ in each treatment during the experiment was obtained through several measurements and estimations. Initial dry weight of shrimp was determined from samples of 50 individuals. Shrimp were washed with distilled water and oven-dried at $60^{\circ} \mathrm{C}$ for $24 \mathrm{~h}$. Individual dry weights were measured using a CAHN model C-33 microbalance with $0.001 \mathrm{mg}$ precision. The same procedure was used to obtain the final weight of the animals in each treatment.

Initial and final energy content of shrimp from each treatment was obtained by means of a calorimeter (Parr), previously calibrated with benzoic acid. The individuals dry weight were transformed into energy units ( $\mathrm{J} \mathrm{mg} \mathrm{dw}{ }^{-1}$ ), and the energy channeled into growth $(P)$ calculated.

Oxygen consumption and ammonia excretion of $\mathrm{PL}_{19}$ were measured in a closed micro-respirometer (RC-300 respiration glass cell, Strathkelvin Instruments, Glasgow, UK). Twenty-four micro-respirometer chambers were connected in series with a constant temperature bath $\left(28 \pm 0.1^{\circ} \mathrm{C}\right)$ using a thermocirculator (Fisher Scientific Isotemp Refrigerated Circulator, model 900) (Brito et al., 2000). Twelve hours fasting postlarvae were individually placed in the respirometric cells with 1.5$\mathrm{mL}$ clean seawater at 10 minutes interval. Before the oxygen consumption measurements, postlarvae were acclimated during 30 minutes in the respirometric chambers. Thereafter, oxygen tension in the chambers' water was measured for a 
10-min period using an oxygen microelectrode (model 781, Strathkelvin Instrument, Glasgow, U.K.). Oxygen meter was calibrated to zero with sodium sulfite solution and to $100 \%$ saturation with full aerated seawater. Oxygen tension in the chambers' water never fell below $80 \%$ saturation level.

Ammonia excretion was evaluated in the same postlarvae used for oxygen consumption measurements. For this purpose, postlarvae were maintained in the respirometric cells for 1.5 hours. Ammonia excretion corresponded to the difference between the ammonia concentration in the water after and before this period. Samples for ammonia determination were stored in Ependorff tubes with sublimated iodine and kept frozen until analysis. After these measurements, postlarvae in the chambers were fed with the corresponding diet for each treatment; one hour later, the procedure was repeated to determine oxygen consumption and ammonia excretion of feeding animals. One control chamber without animals was used for each five experimental chambers. Twenty measurements were recorded per treatment.

Oxygen consumption and ammonia excretion were measured individually in 10 early juvenile $\left(P_{55}\right)$ from each diet by a continuous flow respirometer in a closed system (Rosas et al., 1998). Oxygen tension in water at the entrance and exit of respirometric chambers was measured using an oxygen microelectrode (model 781, Strathkelvin Instrument, Glasgow, U.K.). Oxygen consumption was first determined in 24 hours fasting shrimp which were acclimated during 14 hours in the respirometric chambers. Then, the animals were fed the corresponding diet for each treatment and oxygen consumption measured every one hour from 0900 until 1700. At the same time samples for ammonia determination were stored in Ependorff tubes with sublimated iodine and preserved frozen until analysis. Moulting stage was determined according to the method of Drach and Tchernigovtzeff (1967) adapted for penaeids (Aquacop et al., 1975); only data from shrimps in intermoult stage were retained.

Ammonia concentration in samples was always determined less than 12 hours after sampling, following the method proposed by Strickland and Parsons (1972), adapted by Hernández-López and Vargas-Albores (2003) for small water samples. Water samples $(250 \mu \mathrm{L})$ were mixed in a microplate with $20 \mu \mathrm{L}$ of $10 \%$ phenol solution (in $95 \%$ ethanol), $20 \mu \mathrm{L}$ of $0.5 \%$ sodium nitroprussiate, and $30 \mu \mathrm{L}$ oxidant reactive $(20 \%$ sodium citrate, $1 \%$ sodium hydroxide, and $2.5-\mathrm{mL}$ sodium hypochlorite). The mixture was incubated for 60min at room temperature and optical density was recorded at $655 \mathrm{~nm}$ in a microplate reader (model 550, BioRad, Hercules, CA, USA). Ammonium sulphate was used as a standard (1.5mM).

$R$ was estimated as $R_{\text {rout }}+R_{A H I}$, where $R_{\text {rout }}$ (routine metabolism $\mathrm{mgO}_{2} \mathrm{~h}^{-1} \mathrm{mg} \mathrm{dw}^{-1}$ ) was the oxygen consumption of unfed animal and $\mathrm{R}_{\mathrm{AHI}}$ (apparent heat increment, $\mathrm{mgO}_{2} \mathrm{~h}^{-1} \mathrm{mg} \mathrm{dw}{ }^{-1}$ ) was the difference between the oxygen consumption of unfed animal and the maximum value obtained after feeding. These values were converted to energy by the coefficient $14.3 \mathrm{~J} \mathrm{mg}^{-1} \mathrm{O}_{2}$ (Lucas, 1996). $\mathrm{R}_{\text {rout }}\left(\mathrm{J} \mathrm{d}^{-1} \mathrm{mg}\right.$ $\left.\mathrm{dw}^{-1}\right)$ was estimated considering day time where shrimp were not fed. $R_{A H I}\left(J^{-1}\right.$ $\mathrm{mg} \mathrm{dw}^{-1}$ ) was estimated by the peak of oxygen consumption after feeding and number of rations $(n=3)$ fed to shrimp per day. In the case of young juveniles also the extent $(2 \mathrm{~h})$ of the peak was taken into account in the estimations. 
Similarly, $U$ was estimated as $U_{\text {rou }}+U_{P P N E}$, where $U_{\text {rout }}$ (routine excretion, $\mathrm{mg} \mathrm{N}-\mathrm{NH}_{3}$ $\mathrm{h}^{-1} \mathrm{mg} \mathrm{dw}^{-1}$ ) was the excretion of unfed animals and $U_{\text {PPNE }}$ (post prandial excretion) was the difference between ammonia excretion of unfed animals and the maximum value obtained after feeding. These values were converted to energy by the following coefficient $20.5 \mathrm{~J} \mathrm{mg}^{-1} \mathrm{~N}-\mathrm{NH}_{3}$ (Lucas, 1996). $U_{\text {rout }}\left(\mathrm{J} \mathrm{d}^{-1} \mathrm{mg} \mathrm{dw}^{-1}\right.$ ) was estimated considering day time period where animals were not fed, $U_{P P N E}\left(\mathrm{~J} \mathrm{~d}^{-1} \mathrm{mg}\right.$ $\mathrm{dw}^{-1}$ ) was obtained with the ammonia excretion peak after feeding and number of rations $(n=3)$ fed to shrimp per day. In the case of young juveniles also the extent (2h) of the peak was taken into account for such estimations. The energy content of exuviae (Ev) was considered as $5 \%$ of the total individual energy content (Kurmaly et al., 1989). Energy absorbed (Ab) from feed was calculated as $A b=P+R+U+E_{v}$, where $P$ is the energy channeled into growth, $R$ is the energy lost in respiration, $U$ the energy lost in excretion, and $E_{v}$ is energy content in exuviae. Assimilated energy was calculated as the energy used for biomass production $(P)$, respiration $(R)$, and energy content in exuviae: As $=P+R+E_{v}$. Net growth efficiency $\left(\mathrm{K}_{2}\right)$ that represents the proportion of assimilated energy (or metabolizable energy) channeled into growth was calculated as $K_{2}=\left(P+E_{v}\right) /\left(P+R+E_{v}\right)$ and expressed in percentage (Lucas, 1996). The proportion of assimilated energy invested in production or respiration (P/As, R/As) and a ratio between respiration and production (R/P) were also calculated.

Using oxygen consumption and ammonia excretion data, $\mathrm{O}: \mathrm{N}$ ratio was calculated transforming data to $\mu \mathrm{g} \mathrm{At} \mathrm{h}^{-1} \mathrm{mg} \mathrm{dw}^{-1}$. O:N values of fed shrimp were estimated with maximum oxygen consumption and ammonia excretion after shrimp feeding. Statistical analysis

The Student's $\underline{t}$ analysis was applied to test the effect of feeds on the energy channeled into production, respiration, excretion, exuviae, as well as on the amount of energy absorbed and assimilated. The same procedure was used to test the effect of feeds on O: $\mathrm{N}$ ratios after fasting or feeding periods.

\section{Results}

As result of calorimetric analysis, the initial shrimp $\left(\mathrm{PL}_{14}\right)$ energy content (mean value \pm standard error) was $21.11 \pm 0.81 \mathrm{~J} \mathrm{mg} \mathrm{dw}^{-1}$. Final energy content of shrimp fed animal protein diet (AP) was estimated as $21.11 \pm 0.82 \mathrm{~J} \mathrm{mg} \mathrm{dw}^{-1}$, and final energy content of shrimp fed vegetable protein plus carbohydrate diet (VPC) was $21.10 \pm 0.92 \mathrm{~J} \mathrm{mg} \mathrm{dw}^{-1}(P>0.05)$. Daily energy channeled into respiration and nitrogen excretion values were separated (Table 2) according to routine (fasting period) and active metabolism (feeding period). PL's utilized energy in respiration during routine metabolism $\left(R_{\text {ROUT }}\right)$ significantly higher $(P<0.05)$ in animals fed VPC than AP. Energy expenditure during post-absorptive process $\left(R_{A H I}\right)$ increased significantly $(P<0.05)$ in case of animals fed AP. Early juvenile shrimp follow a similar pattern, although only $R_{A H I}$ was significantly different $(P<0.05)$. Nitrogen excretion showed a significant increment in energy lost in fasting postlarvae $\left(\mathrm{PL}_{19}\right.$ $/ \cup_{\text {ROUT }}$ ) from AP treatment, while the postprandial excretion increased in shrimp fed VPC. In early juveniles ( $\left.P L_{59}\right)$, there was no difference among energy loss in $U_{\text {ROUT }}$ or $U_{P P N E}$ between treatments. However, slightly high values in routine excretion were obtained in shrimp fed AP. Energy balance showed less difference in shrimp fed the two types of feeds on short $\left(\mathrm{PL}_{14}\right.$ to $\left.\mathrm{PL}_{19}\right)$ rather than on long term $\left(\mathrm{PL}_{14}\right.$ to 
$\mathrm{PL}_{59}$ ) periods (Table 3). The amount of energy recovery into production was similar for both diets in a short period, but increased significantly $(P<0.05)$ in shrimp fed AP during a long trial. Postlarvae fed VPC consumed significant higher amount of energy in maintenance $(P<0.05)$. During long periods, energy invested in respiration was the same in both diets. Energy lost in nitrogen wastes was significantly $(P<0.05)$ affected by diets from $\mathrm{PL}_{14}$ to $\mathrm{PL}_{19}$ with higher values in $A P$, but was similar $(P>0.05)$ from $P L_{14}$ to $P L_{59}$. Energy lost in exuviae was the same in both treatments during short period and increased significantly when the long period was analyzed $(P<0.05)$. In relation to absorbed and assimilated energy there was no difference between feeds during short or long periods. Assimilation efficiency, calculated as the proportion of absorbed energy, was high (99 and 90\% during short or long periods respectively) in animals fed VPC. In shrimp fed AP, assimilation efficiency was $89 \%$ during the short period and $86 \%$ for the long term period. Between 41 and 52\% of assimilated energy (As) went to production and it changed according to feed quality and period analyzed (Fig. 1) with a high range of values in shrimp fed AP for both periods. The proportion of assimilated energy invested in maintenance (R/As) fluctuated between 47 and $57 \%$, with a higher value in the VPC treatment for both periods (Fig. 2). The ratio between respiration and production showed that the highest proportion of energy allocated into growth fitted with animals fed AP in both periods. Those animals derived equal quantities of energy for maintenance and production (Fig. 3). Shrimp on VPC treatment during the long period invested for maintenance $50 \%$ energy going to production. Net growth efficiency $\left(\mathrm{K}_{2}\right)$ or the proportion of metabolizable energy channeled into growth was similar during both periods in shrimp fed VPC, though its values were slightly lower than $K_{2}$ value obtained for shrimp fed AP. The highest value was found in shrimp fed AP during long term period (Fig. 4).

Postlarvae under fasting or feeding conditions showed variations in O:N ratio according to the type of feed (Figure 5). Postlarvae fed AP used protein as metabolic substrate during the fasting period. However, the $\mathrm{O}: \mathrm{N}$ ratio increased significantly $(P<0.05)$ after feeding showing a change towards a mixture of metabolic substrates. On the contrary, postlarvae fed VPC utilized lipid and protein as metabolic substrate during fasting with a significant $(P<0.05)$ decrease in $0: N$ ratio after feeding. This reveals the importance of protein as metabolic substrate. In juveniles, O:N ratio variations showed that protein was the main metabolic substrate independently of diet composition or physiological condition (fasting or feeding).

\section{Discussion}

From an ontogenetic point of view, daily energy intake rate of shrimp larvae fed on rotifers was found as high as $5 \mathrm{~J} \mathrm{larvae}^{-1}$ day $^{-1}$ at Protozoea ${ }_{\text {III }}$ before decreasing to 2.6J larvae ${ }^{-1}$ day $^{-1}$ at $\mathrm{PL}_{1}$ (Emmerson, 1984). Larvae fed on rotifers or Artemia, ingest an amount of live preys estimated in a similar range as it is on unicellular algae (Gaxiola et al., 2005). At PL's stage, while feeding on microdiets, the precise assessment of feed intake becomes quite complex. That is the reason why energy partitioning has been expressed from energy density of larvae or PL's (Brito et al., 2004). Feed intake is regulated by energy density (Cuzon and Guillaume, 1997) and it is equivalent in terms of digestible energy $\left(16 \mathrm{~kJ} \mathrm{~g}^{-1}\right)$ between the two feeds. Hence, it was assumed that both crumbled feeds were consumed in a similar 
manner. On the contrary, live food can be consumed differently whether rotifers (2.5 $\mathrm{J} \mathrm{larvae}^{-1}$ day $^{-1}$ ) or Artemia $\left(8 \mathrm{~J} \mathrm{larvae}^{-1}\right.$ day $^{-1}$ ) were ingested probably due to a raptorial effect acting differently (Emmerson, 1984) or a difference in energy content or both. Excretion and respiration rates were measured in order to obtain an indication of digestible energy (DE). This avoided the difficult procedure of collecting feces to obtain a value of apparent digestibility coefficient (ADC) attributed to each category of feed. Protein or energy ADC can be measured on early juveniles even though most studies have been conducted on large size shrimp (Cousin, 1995; Merican and Shim, 1997). Herein, energy partitioning was determined using the method applied to bivalve microphages (Lucas, 1996) and shrimp (Rosas et al., 2001). Coefficients derived from the energy budget expressed differences observed between the two treatments. Recovered energy ( $P$ or RE) did not change with diets on a short period of time ( $\left.P L_{14}-P_{19}\right)$. However, on long term ( $\left.\mathrm{PL}_{14}-\mathrm{PL}_{59}\right) \mathrm{RE}$ from animal fed $\mathrm{AP}$ was higher than that from shrimp feed VPC. Two explanations are put forward: (i) VPC diet reduces feed intake (ii) expenses from metabolism (respiration, excretion) are much higher on PL's fed VPC than with AP. In joules per day, from both treatments PL's respired $2.5 \mathrm{~J}$ and 1.9J $(P<0.05)$ and young juveniles $134 \mathrm{~J}$ and $118 \mathrm{~J}(P>0.05)$ when receiving VPC and $A P$, respectively. In this sense, the second assertion may be correct at least during the stage $P L_{14}-P_{19}$. Ammonia excretion rate was slightly higher with $A P$ but due to the relatively low incidence of excretion on energy budget (U/Abs: 3-10\%), it appeared negligible. Higher apparent heat increment $(\mathrm{AHI})$ with AP than with VPC might be related with a relative higher ammonia excretion rate, but when PPNE/AHI ratio is analyzed, lower values were obtained with AP (4 and 34\% for $\mathrm{PL}_{19}$ and juveniles respectively) than with VPC (12 and 49\% for $\mathrm{PL}_{19}$ and juveniles respectively). Therefore, higher $\mathrm{AHI}$ with $\mathrm{AP}$ could be associated with higher protein content in this diet as $\mathrm{AHI}$ could be related with dietary protein level (Rosas et al., 1996).

$\mathrm{AHI}$ and production in farmed juveniles of $L$. vannamei $\left(25^{\text {th }}\right.$ generation), fed a low cbh-diet were higher than when fed on a high cbh-diet (Arena et al., 2003). Low PPNE/AHI ratio associated with high weight gain was also found in young juveniles L. vannamei (Rosas et al., 1996; 2001) and L. setiferus (Taboada et al., 1998). Ratios such as P/As, R/As, R/P compared for the two diets showed an overall efficiency higher on AP than on VPC. It revealed a greater proportion of energy channeled to production and a lower one to maintenance in animals fed on AP. Metabolic routes for cbh in shrimp coming from massal selection and fed different cbh levels were modified and seemed the result of a drastic reduction in amylase genes allelic frequency (Arena et al., 2003). Then, adaptation of shrimp to use dietary cbh as energy source is not obvious. Farmed population seemed protein dependent and cbh could decrease production efficiency. Net growth efficiency $\left(\mathrm{K}_{2}\right)$ that represents a proportion of assimilated energy (or metabolizable energy) channeled into growth is a good condition index (Lucas, 1996). Assimilation efficiencies of animals fed different diets result in different energy yield for metabolic process and weight gain (Capuzzo, 1981). Estimates of $\mathrm{K}_{2}$ for both short and long term period ( $P_{14-19}$ and $P_{14-59}$ ) confirmed superior efficiency of animals fed AP diet. Values of $\mathrm{K}_{2} \sim 45-50$ corresponding to AP and $\sim 40$ to VPC remained in the same order of magnitude as $\underline{L}$. vannamei early post larvae $\left(\mathrm{K}_{2} \sim 45\right)$ fed on inert 
diet (Brito et al., 2004), and with those for Farfantepenaeus paulensis early post larvae $\left(\mathrm{K}_{2} \sim 44-56\right)$ fed artificial diet at different salinities (Lemos et al., 2001). In essence, maintenance could be at a higher level with PL's fed on VPC than on AP. It is possible that shrimp fed VPC display more mobility while searching for food in experimental tanks. Such an assumption was already addressed by Teshima (1996; pers. com.) with Marsupenaeus japonicus juveniles receiving squid or a soybean concentrate based feed which invested in respiration 20 vs more than 50\%DE respectively. However, considerations taking into account behavioral observations remain uneasy to apply. A similar hypothesis was done in experimental tanks with $\underline{L}$. stylirostris and $\underline{L}$. vannamei juveniles under a post prandial status with glycaemia $\left(3 \mathrm{mg} \mathrm{m}^{-1}\right)$ on a rich-starch feed; unfortunately, no precise observation was done to substantiate such hypothesis (Cousin, 1995).

$\mathrm{O}: \mathrm{N}$ ratio (Mayzaud and Conover,1988) varied between $\mathrm{PL}_{19}$ and $\mathrm{PL}_{59}$. After 5 days adaptation to diets, $\mathrm{PL}_{19}$ shrimp had an $\mathrm{O}: \mathrm{N} \sim 10$ signaling protein as main metabolic substrate in shrimp from AP during fasting, the ratio increased to 60 (use of mixture of lipid and protein) in fed animals. The O:N ratio in the VPC treatment was $\sim 25$ (indicating lipid and protein as metabolic substrates) in fasted shrimp and in post prandial stage this ratio decreased showing an increase in protein use. Interestingly, after 45 days acclimated to diets, $\mathrm{PL}_{59}$ shrimp presented no change in $\mathrm{O}: \mathrm{N}$. The ratio values obtained indicate a use of protein as the main metabolic substrate. These differences might be related on the one hand, to an adaptation to different type of feed that is on line with the omnivorous-opportunist character of $L$. vannamei postlarvae, and to digestive tract development, on the other (Lovett and Felder, 1990b). O:N values with animals fed either AP or VPC indicated an energy derived mainly from protein and lipid. In VPC fed shrimp, difference in energy amount going to production was not related to dietary cbh used as metabolic substrate. The use of cbh as energy source resulting in poor weight gain in $\underline{L}$. vannamei young juveniles (Rosas et al., 2001) may be attributed to cbh inhibiting absorption of amino acids. Energy amount channeled into growth $(P)$ showed differences between shrimp fed AP or VPC diets that do not seem to be related with a use of different metabolic substrate (lipid-protein or cbh-lipid-protein) but rather to energy expended in maintenance. Changes in behavior (mobility in tanks, time spent in searching for food) would explain differences in routing metabolism. This is difficult to quantify and it requires specific designed experiments aimed to that purpose.

Sparing-protein effect with dietary cbh that has previously been documented on wild juveniles of L. vannamei (Arena et al., 2003), is lost through massal selection. This could cause an increase of maintenance cost when cbh are including into the diet. Nevertheless, early juveniles maintained on a grower feed based on vegetable protein instead of animal protein remains a feasible option. Differences in efficiency found through energy budget evaluation seem to be related to the presence of cbh in diet and not to the origin of protein sources. This knowledge may eventually lead to reduce both the fishmeal content in feeds and the amount of waste products, and to contribute to achieve sustainable farming. 


\section{Acknowledgements}

This project was financed by UNAM (project No. IN220502-3) and CONACyT (project No. 41513-Q). We are grateful to Biol. Gabriela Palomino for her assistance in laboratory work. Authors wish to thank Pecis Industries, S.A. de C.V. for $\underline{L}$. vannamei postlarvae supply.

\section{References}

Aquacop, Bourgeois, B., and Cuzon, G., 1975. Détermination des stades d'intermue chez Macrobrachium rosenbergii (Caridae) and Penaeus merguiensis (Penaeidae). Cnexo/COP, Internal Report, 40 pp.

Aquacop 1995. Determination of apparent digestive coefficient for three different quality of fishmeal fed post juveniles Litopenaeus stylirostris. Proceedings Annual Meeting WAS, San Diego, USA, Feb. 1995.

Arena, L., Cuzon, G., Pascual, C., Gaxiola, G., Soyez, C., Van Wormhoudt, A., Rosas, C., 2003. Physiological and genetic variations in domesticated and wild populations of Litopenaeus vannamei fed with different carbohydrates levels. J. Shellfish Res. 22(1), 269-279.

Argue, BJ., Cody, J., Arce, SM., Forster, IP., Moss, SM. and Tacon, AGJ. 2001. Performances of selectively bred L.vannamei fed low protein and vegetable protein diets. In Book of abstracts, Aquaculture, Lake Buena Vista, FL (USA),21-25 Jan.2001.

Brito, R., Chimal, M.E., Gaxiola, G., Rosas, C., 2000. Growth, metabolic rate, and digestive enzyme activity in the white shrimp Litopenaeus setiferus early postlarvae fed different diets. J. Exp. Mar. Biol. Ecol. 255, 21-36.

Brito, R., Chimal E., Gelabert R., Gaxiola G., Rosas C., 2004. Effects of artificial and natural diets on energy allocation in Litopenaeus setiferus (Linnaeus, 1767) and Litopenaeus vannamei (Boone, 1931) early postlarvae. Aquaculture 237, 517531.

Camara, M.R., Coutteau, P., Sorgeloos, P., 1997. Dietary phosphatidylcholine requirements in larval and postlarval Penaeus japonicus Bate. Aquac. Nutr. 3(1), 39-47.

Capuzzo, J.M., 1981. Crustacean bioenergetics: role of environmental variables and dietary levels of macronutrients on energetic efficiencies. In: Pruder, G.D., Langdon, C.J., Conklin, D.E., (Eds.) Proceedings of the 2nd Intl Conf. on Aquaculture Nutrition: Biochemical and Physiological Approaches to Shellfish Nutrition, October 27-29, 1981, Lewes/Rehoboth Beach, Delaware. Baton Rouge, LA. LSU, Division of Continuing Education, 71-86. 
Colvin, L.V., Brand, C.W., 1977. The protein requirement of penaeid shrimp at various life-cycle stages in controlled environment systems. In: Proceedings of the Eighth Annual Meeting World Mariculture Society, Charleston, SC (USA) Publ. by: Louisiana State University. Division of Continuing Education; Baton Rouge, LA (USA), 821-840.

Cousin, M., 1995. Contribution à l'étude de l'utilisation des glucides et du rapport

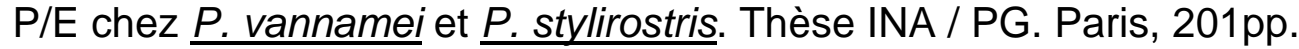

Cuzon, G., Guillaume, J., 1997. Protein/Energy in shrimp. Book on Crustacea nutrition, International Working Group on Crustacea Nutrition, World Aquaculture Society, 51-70.

Dittel, A.I., Epifanio, C.E., Cifuentes, L.A., Kirchman, D.L., 1997. Carbon and nitrogen sources for shrimp postlarvae fed natural diets from a tropical mangrove system. Estuarine Coastal and Shelf. Sc. 45(5), 629-637.

Drach, P., Tchernigovtzeff, C., 1967. Sur la méthode de détermination des stades d'intermue et son application générale aux crustacés. Vie et Milieu, Biologie Marine, 8(3), 595-610.

Emmerson, W.D., 1984. Predation and energetics of Penaeus indicus (Decapoda:Penaeidae) larvae feeding on Brachionus plicatilis and Artemia nauplii. Aquaculture 38(3), 201-209.

Escobar Briones, E., 1988. Variación en la dieta de postlarvas y juveniles de camarón en observaciones de campo. Acuavision 3(14), 27-29.

Gallardo, P.P., Martínez, G., Brito, A., Barrera, J., Pedroza-Islas, R., Cuzon, G., Rosas, C., Gaxiola, G., 2003. Effect of Artemia nauplii replacement by an artificial feed containing krill hydrolysate on ingestion rate, oxygen consumption, and energy budget in the mysis of Litopenaeus vannamei (Boone, 1931). Nauplius $11(2), 69-81$.

Garcia, S., Le Reste, L., 1981. Life cycle, dynamics, exploitation and management of coastal penaeid shrimp stocks. FAO Fisheries Technical Paper. No.203. Rome. FAO. 1981, 215p.

Gaxiola, G., Cuzon, G., García, T.J., Taboada, G., Brito, R., Chimal, M.E., Paredes, A., Rosas, C., 2005. Modelling ingestion rate and metabolism with Farfantepenaeus brasiliensis larvae fed microalgae. Poster Symposium Fourth Crustacean Larval Conference, University of Glasgow, july 2005, p 67.

Hernández-López, J., Vargas-Albores, F., 2003. A microplate technique to quantify nutrients $\left(\mathrm{NO}_{2}{ }^{-}, \mathrm{NO}_{3}{ }^{-}, \mathrm{NH}_{4}{ }^{+}\right.$and $\left.\mathrm{PO}_{4}{ }^{3-}\right)$ in seawater. Aquac. Res. 34, 1201-1204. 
Immanuel, G., Palavesam, A., Petermarian, M., 2001. Effects of feeding lipid enriched Artemia nauplii on survival, growth, fatty acids and stress resistance of postlarvae Penaeus indicus. Asian Fisheries Science 14(4), 377-388.

Kurmaly, K., Yule, A.B., Jones, D.A., 1989. An energy budget for the larvae of Penaeus monodon (Fabricius). Aquaculture 81, 13-25.

Lemos, D., Phan, V. N., 2001. Ontogenetic variation in metabolism, biochemical composition and energy content during the early life stages of Farfantepenaeus paulensis (Crustacea: Decapoda: Penaeidae). Mar. Biol. 138, 985-997.

Lemos, D., Phan, V. N., Alvarez, G., 2001. Growth, oxygen consumption, ammonia-N excretion, biochemical composition and energy content of Farfantepenaeus paulensis Perez-Farfante (Crustacea, Decapoda, Penaeidae) early postlarvae in different salinities. J. Exp. Mar. Biol. Ecol. 261, 55-74.

Lovett, D.L., Felder, D.L., 1989. Ontogeny of gut morphology in the white shrimp Penaeus setiferus (Decapoda, Penaeidae). J. Morphol. 201, 253-272.

Lovett, D.L., Felder, D.L., 1990a. Ontogenetic change in digestive enzyme activity of larval and postlarval white shrimp Penaeus setiferus (Crustacea, Decapoda, Penaeidae). Biol. Bull. 178(2), 144-159.

Lovett, D.L., Felder, D.L., 1990b. Ontogenetic changes in enzyme distribution and midgut function in developmental stages of Penaeus setiferus (Crustacea, Decapoda, Penaeidae). Biol. Bull. 178(2), 160-174.

Lovett, D.L., Felder, D.L., 1990c. Ontogeny of kinematics in the gut of the white shrimp Penaeus setiferus (Decapoda:Penaeidae). J. Crust. Biol. 10(1), 53-68.

Lucas, A., 1996. Bioenergetics of Aquatic Animals. Taylor and Francis, London, $169 \mathrm{pp}$.

Mayzaud, P., Conover, R.J., 1988. O:N atomic ratio as a tool to describe zooplankton metabolism. Mar. Ecol. Prog. Ser. 45, 289-302.

Merican, Z.O., Shim, K.F., 1997. Quantitative requirements of linolenic and docosahexanoic acid for juvenile Penaeus monodon. Aquaculture 157, 277-295.

Rees, J.F., Cure, K., Piyatiratitivorakul, S., Sorgeloos, P., Menasveta, P., 1994. Highly unsaturated fatty acid requirements of Penaeus monodon postlarvae: An experimental approach based on Artemia enrichment. Aquaculture 122(2-3), 193207.

Rosas, C., Sánchez, A., Díaz, E., Soto, L.A., Gaxiola, G., Brito, R., 1996. Effect of dietary protein level on apparent heat increment and post-prandial nitrogen 


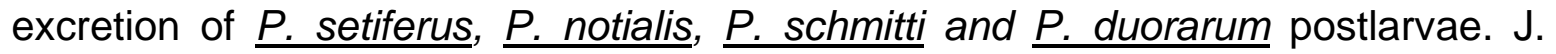
World Aquac. Soc. 27, 92-102.

Rosas, C., Martínez, E., Gaxiola, G., Díaz, E., Brito, R., Soto, L.A., 1998. Effect of dissolved oxygen on the energy balance and survival of Penaeus setiferus juveniles. Mar. Ecol. Prog. Ser. 174, 67-75.

Rosas, C., Cuzon, G., Taboada, G., Pascual, C., Gaxiola, G., Van Wormhoudt, A., 2001. Effect of dietary protein and energy levels on growth, oxygen consumption, hemolymph and digestive gland carbohydrates, nitrogen excretion and osmotic pressure of Litopenaeus vannamei and $\underline{L}$. setiferus juveniles (Crustacea, Decapoda, Penaeidae). Aquac. Res. 32, 531-547.

Sheen, S.S., Huang, H.T., 1998. The effects of different protein sources on the survival of grass shrimp, Penaeus monodon (Fabricius, 1798) larvae from zoea to postlarva (Decapoda, Natantia). Crustaceana 71(8), 909-924.

Strickland, J.D., Parsons, T.R., 1972. A Practical Handbook of Seawater Analysis, $2^{\text {nd }}$ edition. Fisheries Res. Bd. Canada.

Taboada, G., Gaxiola, G., García, T., Pedroza, R., Sánchez, A., Soto, L.A., Rosas, C., 1998. Oxygen consumption and ammonia-N excretion related to protein requirements for growth of white shrimp Penaeus setiferus. Aquac. Res. 29, 1-11.

Velasco, M., Lawrence, A.L., Neil, W.H., 1998. Effects of dietary phosphorus level and inorganic source on survival and growth of Penaeus vannamei postlarvae in zero-water exchange culture tanks. Aquat. Living Resour. 11(1), 29-33. 
Table 1. Composition (\% dry weight) and analysis of experimental feeds.

\begin{tabular}{lcc}
\hline Ingredients & AP & VPC \\
\hline fish meal & 19 & - \\
CPSP-70* & 9 & 5 \\
shrimp meal & 5 & - \\
squid meal & 30 & - \\
\hline wheat starch & - & 14 \\
soybean SPC** & - & 20 \\
wheat gluten & - & 10 \\
Spirulina & - & 21 \\
\hline cholesterol & 0.56 & 0.56 \\
super Selco & 3.7 & 4 \\
soybean lecithin & 2 & 2 \\
carophyll-red & 0.02 & 0.02 \\
vitamin mix*** & 1 & 1.5 \\
sodium alginate & 1 & 1 \\
filler & 19 & 21 \\
& & \\
protein \% & 51 & 40 \\
lipid \% & 11 & 11 \\
carbohydrate \% & 3 & 20 \\
digestible energy & 16 & 16 \\
(J/mg) & & \\
\hline Animal protein diet (AP) & and & vegable protein
\end{tabular}

Animal protein diet (AP) and vegetable protein and carbohydrate diet (VPC).

* Soluble fish protein concentrate (Sopropêche, Boulogne s/mer, France) ** Soy soluble protein concentrate

*** Rovimix \# 1720, Roche, Bâle, Suisse 
Table 2. Respiration and excretion in fasting and fed postlarvae $\left(\mathrm{PL}_{19}\right)$ and early juveniles $\left(\mathrm{PL}_{59}\right)$ of $\underline{L}$. vannamei fed different diets (mean values \pm standard error). All values expressed in $\mathrm{J} \mathrm{day}^{-1}$.

\begin{tabular}{|c|c|c|c|c|c|c|c|c|}
\hline $\begin{array}{c}\text { Stage/ } \\
\text { Diet }\end{array}$ & $\mathrm{R}_{\text {ROUT }}$ & $p$ & $\mathrm{R}_{\mathrm{AHI}}$ & $p$ & $U_{\text {ROUT }}$ & $p$ & $U_{\text {PPNE }}$ & $p$ \\
\hline \multicolumn{9}{|l|}{$\left(\mathrm{PL}_{19}\right)$} \\
\hline \multirow[t]{2}{*}{ AP } & $1.19 \pm 0.13$ & & $0.68 \pm 0.07$ & & $0.195 \pm 0.021$ & & $0.025 \pm 0.003$ & \\
\hline & & 0.023 & & 0.000 & & 0.002 & & 0.015 \\
\hline $\begin{array}{l}\text { VPC } \\
\left(\mathrm{PL}_{59}\right)\end{array}$ & $1.77 \pm 0.25$ & & $0.33 \pm 0.04$ & & $0.114 \pm 0.014$ & & $0.039 \pm 0.005$ & \\
\hline \multirow[t]{2}{*}{ AP } & $84.36 \pm 13.97$ & & $35.05 \pm 3.02$ & & $18.97 \pm 4.46$ & & $11.95 \pm 2.89$ & \\
\hline & & 0.133 & & 0.006 & & 0.154 & & 0.435 \\
\hline VPC & $110.76 \pm 17.54$ & & $23.18 \pm 2.57$ & & $13.91 \pm 1.33$ & & $11.34 \pm 2.18$ & \\
\hline
\end{tabular}

(AP) animal protein diet, (VPC) vegetable protein and carbohydrate diet. $p$ is the probability from Student's $\underline{t}$ analysis at 0.05 . 
Table 3. Energy channeled into production $(P)$, respiration $(R)$, excretion $(U)$, and exuviae $\left(E_{v}\right)$ during postlarvae $\left(\mathrm{PL}_{14}-\mathrm{PL}_{19}\right)$ and early juvenile development $\left(\mathrm{PL}_{14^{-}}\right.$ $\left.P L_{59}\right)$ of $L$. vannamei fed different diets (mean values \pm standard error). $A b$, absorbed energy $\left(A b=P+R+U+E_{v}\right)$, As, assimilated energy $\left(A s=P+R+E_{v}\right)$. All values expressed in $\mathrm{J}$ day $^{-1}$.

\begin{tabular}{|c|c|c|c|c|c|c|}
\hline Stage/Diet & $P$ & $R$ & $U$ & $E_{v}$ & $A b$ & As \\
\hline \multicolumn{7}{|l|}{$\left(\mathrm{PL}_{14}-\mathrm{PL}_{19}\right)$} \\
\hline AP & $2.04 \pm 0.45$ & $1.87^{\mathrm{b}} \pm 0.16$ & $0.23^{\mathrm{a}} \pm 0.03$ & $0.11 \pm 0.02$ & $4.46 \pm 0.77$ & $3.95 \pm 0.67$ \\
\hline VPC & $2.05 \pm 0.44$ & $2.50^{a} \pm 0.29$ & $0.15^{b} \pm 0.01$ & $0.10 \pm 0.02$ & $4.79 \pm 0.74$ & $4.76 \pm 0.74$ \\
\hline \multicolumn{7}{|l|}{$\left(\mathrm{PL}_{14}-\mathrm{PL}_{59}\right)$} \\
\hline AP & $115.9^{a} \pm 10.6$ & $118.5 \pm 16.0$ & $31.0 \pm 5.4$ & $5.8^{a} \pm 0.5$ & $283.3 \pm 29.8$ & $243.8 \pm 23.8$ \\
\hline VPC & $88.4^{b} \pm 10.1$ & $133.9 \pm 20.0$ & $20.2 \pm 5.8$ & $4.4^{b} \pm 0.5$ & $214.0 \pm 43.6$ & $192.5 \pm 46.9$ \\
\hline
\end{tabular}
(VPC) vegetable protein and carbohydrate diet. 
Fig. 1. Proportion of assimilated energy channeled into production (P/As) for $P L_{14-}$ 19 and $\mathrm{PL}_{14-59} \underline{L}$. vannamei fed AP animal protein feed or VPC vegetable protein and carbohydrate feed.

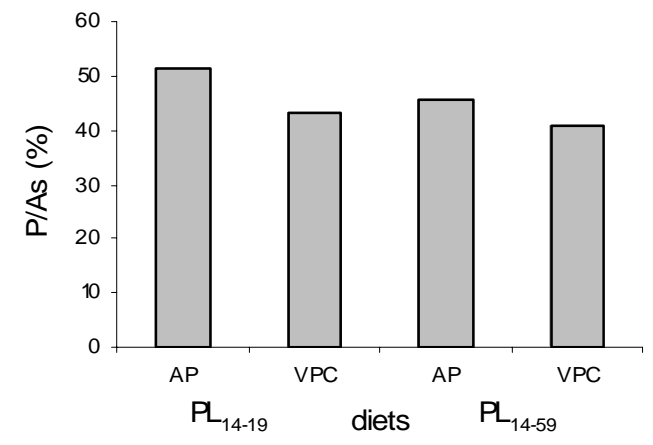

Fig. 2. Proportion of assimilated energy used in respiration (R/As) for $P L_{14-19}$ and $\mathrm{PL}_{14-59}$ L. vannamei fed AP animal protein feed or VPC vegetable protein and carbohydrate feed.

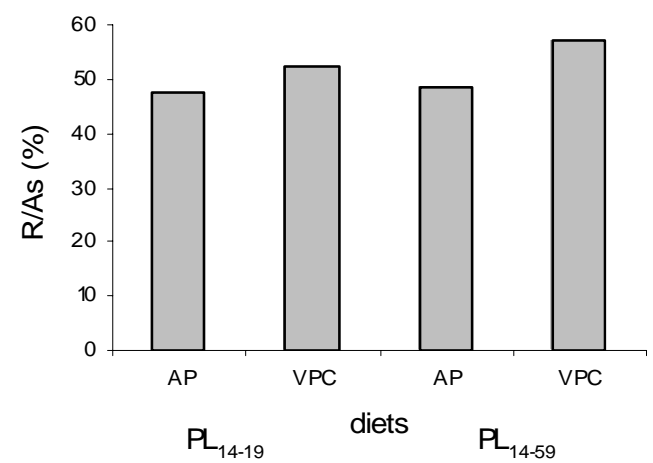


Fig. 3. Ratio between energy channeled into respiration and growth $(R / P)$ for $P L_{14-}$ 19 and $\mathrm{PL}_{14-59} \underline{\mathrm{L}}$. vannamei fed $\mathrm{AP}$ animal protein feed diet and VPC vegetable protein and carbohydrate feed.

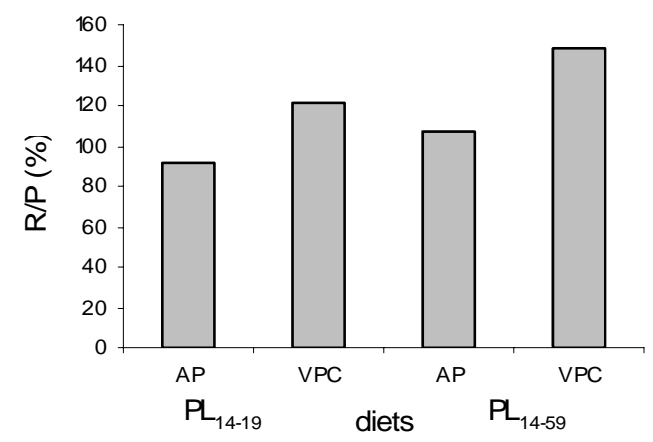

Fig. 4. Net growth efficiency $\left(\mathrm{K}_{2}\right)$ for $\mathrm{PL}_{14-19}$ and $\mathrm{PL}_{14-59}$ L. vannamei fed $A P$ animal protein feed or VPC vegetable protein and carbohydrate feed. $\left(^{*}\right) p<0.05$ ), (ns) $p>0.05$. Lines represent the standard error.

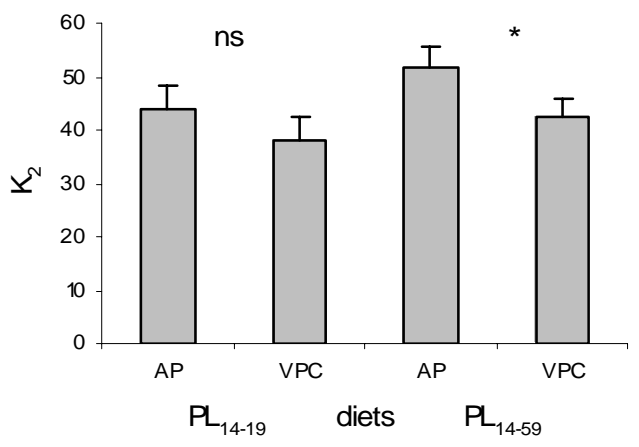


Fig. 5. O:N ratio for $P L_{19}$ and juveniles $\left(P L_{59}\right) \underline{L}$. vannamei fed $A P$ animal protein feed or VPC vegetable protein and carbohydrate feed. $\left(^{*}\right) P<0.05$, (ns) $P>0.05$. Lines represent the standard error.

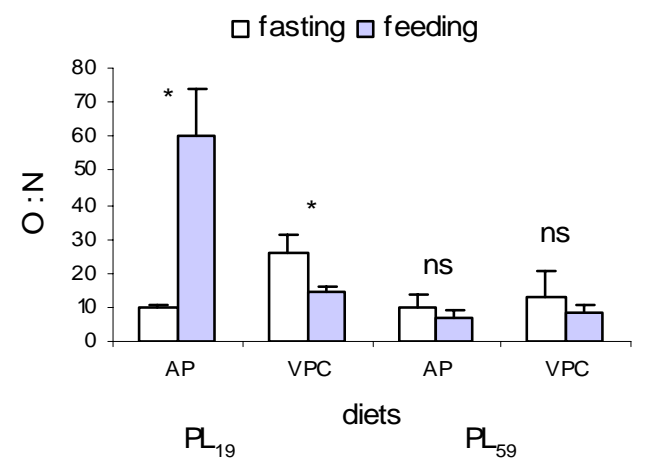

